\title{
Influence of Different Levels of Sulphur and Boron Nutrition on Nutrient Uptake and Yield of Summer Sesame in West Bengal
}

\author{
Basant Kumar $^{1 *}$, Narayan Chandra Sarkar ${ }^{1}$ and Ayesha Fatima ${ }^{2}$ \\ ${ }^{1}$ Department of Agronomy, PSB Sriniketan, W.B., India \\ ${ }^{2}$ Division of Agronomy, ICAR-Indian Agricultural Research Institute, New Delhi, India \\ *Corresponding author
}

\section{Keywords}

Sesame, Sulphur, Boron, Nutrient uptake and yield

Article Info

Accepted:

08 January 2020

Available Online:

10 February 2020

A B S T R A C T

A field experiment was conducted during pre-kharif 2017 at the Agricultural Farm, Palli Siksha Bhavana, Visva-Bharati, Sriniketan, Birbhum, West Bengal to study the effect of different levels of sulphur and boron on nutrient uptake and yield of summer sesame under red lateritic soil of West Bengal. The experiment was laid out in factorial randomized block design comprising of two factors (sulphur and boron) and eight treatment combinations replicated thrice. Sulphur was soil applied one month before sowing and foliar spray of boron was done at 45 days after sowing. The experimental findings revealed that the uptake of nitrogen, phosphorus, potassium and sulphur was significantly higher with the application of sulphur @ $45 \mathrm{~kg} / \mathrm{ha}$ and foliar application of $0.15 \%$ of boron. The grain and stover yield were also statistically higher in the treatment sulphur@ $95 \mathrm{~kg} / \mathrm{ha}$ among the sulphur treatments and with the foliar spray of $0.15 \%$ boron. Thus, from the results of the present experiment it can be concluded that sulphur and boron play an important role in enhancing the yield as well as uptake of different nutrients.

\section{Introduction}

Sesame is drought resistant crop, which can be easily grown under rainfed conditions. About $75 \%$ of oilseed cultivated area is rainfed, where there are wide fluctuations in oilseeds production in response to aberration in weather conditions related mainly to amount and distribution of rainfall. Sulphur and boron are two essential nutrients regarded as inevitable in the production phenology of any oilseed crops. Sulphur nutrition plays an important role in improving the growth and productivity of sesame (Saren et al., 2004). Sulphur is needed for the synthesis of other metabolites, including coenzyme A, biotin, thiamine or vitamin B1 and glutathione. Moreover continuous application of NPK fertilizers results in sulphur deficiency along with very much deficit of organic matter 
make the situation more worst for oilseed crops. Boron deficiency is one of the most widespread micronutrient deficiency in India. Boron is involved in pollen germination. Both deficiency and toxicity cause lower chlorophyll content and rate of photosynthesis and may induce cell wall synthesis by an influence on the activity of the plasma lemma and can disturb the maintenance of meristem in the plant. Boron is required for pollen germination and pollen tube growth (Dugger, 1983).

\section{Materials and Methods}

A field experiment, "Effect of Sulphur and Boron on growth and productivity of sesame (Sesamum indicum L.) during summer season" was conducted in the Agricultural Farm of Palli Siksha Bhavana, Visva-Bharati, Sriniketan during pre-kharif season of 2017 to study the effect of sulphur and boron nutrition on growth and productivity of sesame. The experiment was laid out in factorial randomized block design with eight treatment combinations, replicated thrice in $4 \times 3 \mathrm{~m}$ plots. The chemical analysis of the top $15 \mathrm{~cm}$ soil showed that the soil was slightly acidic in reaction, low level of organic carbon, available nitrogen and potassium content and medium in available phosphorus. The treatments are: $\mathrm{T}_{1}$ : Absolute control, $\mathrm{T}_{2}$ : Only boron@0.15\%, T3: Only sulphur@15kg/ha, T4: Sulphur@15 kg/ha+Boron @0.15\%, T5: Only sulphur@30kg/ha, T6: Sulphur@30 kg/ha+Boron@0.15\%, T : OnlySulphur@ 45 kg/ha, T8: Sulphur@45kg/ha+Boron@ $0.15 \%$. The source of sulphur, elemental sulphur was applied at 1 month before sowing of grain followed by application of lime at 25 $\mathrm{kg} / \mathrm{ha}$ and boron was applied at 45 days after sowing (DAS). Sesame cultivar Tilottoma was taken for the study. Recommended doses of $\mathrm{N}, \mathrm{P}$ and $\mathrm{K}(60 \mathrm{~kg} / \mathrm{ha}$ as urea, $40 \mathrm{~kg} / \mathrm{ha}$ as DAP and $40 \mathrm{~kg} / \mathrm{ha}$ as MOP) were applied. The data recorded on various parameters were subjected to statistical analysis by the analysis of variance method (Panse and Sukhatme, 1967). The significance of different sources of variations was tested by error mean square of Fisher and Snedecor's 'F'test at probability level 0.05. Fisher and Yate's tables were consulted for the determination of critical difference at $5 \%$ level of significance. The value standard error of mean $(\mathrm{S}$. Em \pm ) and the critical difference (C. D.) were used to compare the difference between the treatment means.

\section{Results and Discussion}

\section{Nitrogen uptake (kg/ha)}

The highest $(14.87 \mathrm{~kg} / \mathrm{ha})$ uptake of nitrogen by grain was found in the treatment sulphur @ $45 \mathrm{~kg} / \mathrm{ha}$ and this was significantly higher than other treatments. The treatment sulphur @ $45 \mathrm{~kg} / \mathrm{ha}$ registered $6.05 \%, 18.89 \%$ and $27.84 \%$ higher uptake over the treatment with sulphur@30 kg/ha, sulphur @ 15 kg/ha and no sulphur, respectively. Boron treatment @ $0.15 \%$ foliar spray also significantly increased nitrogen uptake by grain registering $12.29 \%$ higher nitrogen uptake when compared to treatment without foliar spray of boron. In the case of nitrogen uptake by stover, maximum (16.05 kg/ha) uptake was recorded in the sulphur@45 kg/ha treatment. This treatment recorded $7.01 \%, 16.39 \%$ and $25.90 \%$ higher uptake of nitrogen by stover over the treatments with sulphur @ $30 \mathrm{~kg} / \mathrm{ha}, 15 \mathrm{~kg} / \mathrm{ha}$ and no sulphur application, respectively. Boron application @ 0.15\% foliar spray also recorded higher $(14.61 \mathrm{~kg} / \mathrm{ha})$ uptake by $5.94 \%$ over the treatment with no boron application. The data on total uptake of nitrogen by grain and stover revealed that highest $(30.92 \mathrm{~kg} / \mathrm{ha})$ total uptake of nitrogen was found in the treatment sulphur @45 $\mathrm{kg} / \mathrm{ha}$ which was significantly higherthan other treatments. It was observed that sulphur @ $45 \mathrm{~kg} / \mathrm{ha}$ registered $7.54 \%, 34.96 \%$ and 
$19.61 \%$ higher total uptake of nitrogen over the treatments with sulphur @ $30 \mathrm{~kg} / \mathrm{ha}$, sulphur @ 15 kg/ha and no sulphur application respectively. The foliar spray of boron@0.15\% also recorded significantly higher $(28.37 \mathrm{~kg} / \mathrm{ha})$ total nitrogen uptake than the treatment without foliar spray of boron. Application of sulphur @ $45 \mathrm{~kg} / \mathrm{ha}$ have shown significant increase in nitrogen uptake due to its role in increase in nutrient uptake. The increased uptake of nitrogen was due to synergistic interaction effect of $\mathrm{N}$ and $\mathrm{S}$ and higher dry matter accumulation. These results were in conformity with the findings of Jeena et al., (2013).

\section{Phosphorus uptake (kg/ha)}

The findings revealed that sulphur @ 45 $\mathrm{kg} / \mathrm{ha}$ recorded maximum $(5.25 \mathrm{~kg} / \mathrm{ha})$ phosphorus uptake by grain over other treatments. Sulphur @ $45 \mathrm{~kg} / \mathrm{ha}$ recorded $3.55 \%$ and $12.41 \%$ higher phosphorus uptake by grain as compared to treatments with sulphur @ $30 \mathrm{~kg} / \mathrm{ha}$ sulphur and @ $15 \mathrm{~kg} / \mathrm{ha}$, respectively. The foliar spray of boron @ $0.15 \%$ also registered significantly higher (4.91 kg/ha) phosphorus uptake by grain. This treatment recorded $6.50 \%$ higher uptake as compared to no boron application. The data on phosphorus uptake by stover revealed that highest $(7.29 \mathrm{~kg} / \mathrm{ha})$ phosphorus uptake was registered in sulphur @ $45 \mathrm{~kg} / \mathrm{ha}$. The treatment sulphur @ $45 \mathrm{~kg} / \mathrm{ha}$ recorded $37.28 \%, \quad 104.77 \%$ and $147.11 \%$ higher phosphorus uptake when compared to treatments. The foliar spray of $0.15 \%$ boron also registered higher $(5.27 \mathrm{~kg} / \mathrm{ha})$ phosphorus uptake by stover while lower $(4.27 \mathrm{~kg} / \mathrm{ha})$ phosphorus uptake was observed in treatment with no foliar spray of boron. In the case of total phosphorus uptake by grain and stover the treatment sulphur @ $45 \mathrm{~kg} / \mathrm{ha}$ was found to have $20.82 \%, 52.24 \%$ and $79.51 \%$ more uptake of phosphorus over other treatments. Boron application of $0.15 \%$ foliar spray recorded higher $(10.18 \mathrm{~kg} / \mathrm{ha})$ total phosphorus uptake by grain and stover which was about $12.77 \%$ higher than no boron treatment. The increase in uptake of phosphorus with sulphur levels might be due to increase in grain and stover yield of sesame. Similar results were obtained by Jadav et al., (2010).

\section{Potassium uptake (kg/ha)}

In the case of potassium uptake by grain, maximum $(6.00 \mathrm{~kg} / \mathrm{ha})$ uptake was recorded in the sulphur@45 kg/ha treatment. This treatment recorded $11.31 \%, 46.67 \%$ and $69.01 \%$ higher uptake of potassium by grain over the treatments with sulphur @ $30 \mathrm{~kg} / \mathrm{ha}$, sulphur @ $15 \mathrm{~kg} / \mathrm{ha}$ and no sulphur application, respectively. Application of $0.15 \%$ foliar spray recorded higher (5.14 $\mathrm{kg} / \mathrm{ha}$ ) potassium uptake which was about $17.35 \%$ higher than no foliar spray of boron. The maximum $(16.38 \mathrm{~kg} / \mathrm{ha})$ uptake of potassium by stover was found in the treatment sulphur@ $@ 5$ kg/ha and this was significantly higher over other treatments. The treatment sulphur @ $45 \mathrm{~kg} / \mathrm{ha}$ registered $10.49 \%, \quad 27.47 \%$ and $58.87 \%$ higher potassium uptake over the treatments with sulphur @ $30 \mathrm{~kg} / \mathrm{ha}$, sulphur @ $15 \mathrm{~kg} / \mathrm{ha}$ and no sulphur, respectively. Boron treatment @ $0.15 \%$ foliar spray also significantly increased potassium uptake by stover registering7.79 \% higher $(14.11 \mathrm{~kg} / \mathrm{ha})$ potassium uptake when compared to treatment without foliar spray of boron. The data on total uptake of potassium by grain and stover revealed that highest $(22.37 \mathrm{~kg} / \mathrm{ha})$ total uptake of potassium was observed in the treatment sulphur @ $45 \mathrm{~kg} / \mathrm{ha}$ which was significantly higher than other treatments. It was observed that sulphur @ 45 $\mathrm{kg} / \mathrm{ha}$ registered $10.52 \%$ and $61.39 \%$ higher total uptake of potassium over the treatments with sulphur@30 kg/ha and no sulphur application, respectively. The foliar spray of boron@ $0.15 \%$ also recorded significantly 
higher $(19.24 \mathrm{~kg} / \mathrm{ha})$ total potassium uptake than the treatment without foliar spray of boron.

Application of sulphur @ $45 \mathrm{~kg} / \mathrm{ha}$ have shown significant increase in potassium uptake due to its role in increase in dry matter and nutrient uptake. Similar views were reported by Jadav et al., (2010).

\section{Sulphur uptake (kg/ha)}

In the case of sulphur uptake by grain, highest $(12.83 \mathrm{~kg} / \mathrm{ha})$ uptake was recorded in the sulphur @ $45 \mathrm{~kg} / \mathrm{ha}$ treatment. This treatment recorded $23.36 \%, 40.21 \%$ and $300.93 \%$ higher uptake of sulphur by grain over the treatments with sulphur @ $30 \mathrm{~kg} / \mathrm{ha}$, sulphur @ $15 \mathrm{~kg} / \mathrm{ha}$ and no sulphur application, respectively. Boron application of $0.15 \%$ foliar spray recorded higher $(9.67 \mathrm{~kg} / \mathrm{ha})$ sulphur uptake by grain over treatment with no boron and this was about $19.08 \%$ higher than no boron treatment. The findings on the data on sulphur uptake by stover revealed that sulphur @ $45 \mathrm{~kg} / \mathrm{ha}$ recorded maximum (2.87 $\mathrm{kg} / \mathrm{ha}$ ) sulphur uptake by stover over other treatments. This treatment was statistically at par with the treatment sulphur @ $30 \mathrm{~kg} / \mathrm{ha}$. Sulphur @ $45 \mathrm{~kg} / \mathrm{ha}$ recorded $73.39 \%$ and $165.74 \%$ higher sulphur uptake by stover as compared to treatments sulphur @ $15 \mathrm{~kg} / \mathrm{ha}$ and without sulphur, respectively.

The foliar spray of boron @ $0.15 \%$ also registered significantly higher $(2.31 \mathrm{~kg} / \mathrm{ha})$ sulphur uptake by stover. This treatment recorded $25.54 \%$ higher uptake of sulphur as compared to no boron application. In the case of total sulphur uptake by grain and stover the treatment sulphur@ $@ 45 \mathrm{~kg} / \mathrm{ha}$ was found to have highest $(15.70 \mathrm{~kg} / \mathrm{ha})$ total sulphur uptake. Sulphur @ $45 \mathrm{~kg} / \mathrm{ha}$ recorded 19.84\%, $45.37 \%$ and $266.82 \%$ more uptake of sulphur over treatments with sulphur @ $30 \mathrm{~kg} / \mathrm{ha}$, sulphur @ 15 kg/ha and no sulphur application, respectively. Boron application of $0.15 \%$ foliar spray recorded higher (11.99 $\mathrm{kg} / \mathrm{ha}$ ) total phosphorus uptake by grain and stover overtreatment with no boron. It was about $20.50 \%$ higher than no boron treatment.

Application of S significantly increased the $\mathrm{S}$ uptake by sesame grain and stover. This increase in $\mathrm{S}$ uptake may be attributed to increase in $\mathrm{S}$ concentration in plant and dry matter yield. The results corroborated the findings of Dwidevi et al., (2002).

\section{Grain and stover yield (kg/ha)}

It was observed that grain yield increased with increasing sulphur levels and highest $(1217.71 \mathrm{~kg} / \mathrm{ha})$ grain yield was obtained in the treatment sulphur @ $45 \mathrm{~kg} / \mathrm{ha}$. The treatment sulphur @ $45 \mathrm{~kg} / \mathrm{ha}$ recorded $6.17 \%, 15.44 \%$ and $24.09 \%$ higher yield than the treatment with sulphur @ $30 \mathrm{~kg} / \mathrm{ha}$, sulphur @ 15 kg/ha and no sulphur respectively. The treatment sulphur @ 30 $\mathrm{kg} / \mathrm{ha}$ recorded $8.72 \%$ and $16.87 \%$ higher grain yield over the treatment with sulphur @ $15 \mathrm{~kg} / \mathrm{ha}$ and no sulphur, respectively.

The treatment with $0.15 \%$ foliar spray of boron registered higher $(1129.78 \mathrm{~kg} / \mathrm{ha})$ grain yield as compared to treatment without foliar spray of boron. The same treatment recorded $5.53 \%$ higher yield than the treatment without boron application. Similarly, Nagavani et al., (2001) and Maragatham et al., (2006) reported that application of sulphur at 40 $\mathrm{kg} / \mathrm{ha}$ increased grain yield $(402 \mathrm{~kg} / \mathrm{ha})$ over control and $20 \mathrm{~kg} \mathrm{~S} / \mathrm{ha}$ of sesame.

The highest $(3583.33 \mathrm{~kg} / \mathrm{ha})$ stover yield was obtained in the treatment sulphur @ $45 \mathrm{~kg} / \mathrm{ha}$ and it produced $4.12 \%$ and $12.79 \%$ higher yield over treatments with sulphur @ 30 $\mathrm{kg} / \mathrm{ha}$ and $15 \mathrm{~kg} / \mathrm{ha}$, respectively. 
Table.1 Effect of different levels of sulphur and boron nutrition on nutrient uptake and yield of summer sesame

\begin{tabular}{|c|c|c|c|c|c|c|c|c|c|c|c|c|c|c|}
\hline \multirow[t]{2}{*}{ Treatments } & \multicolumn{3}{|c|}{$\begin{array}{c}\text { Nitrogen uptake } \\
\text { (kg/ha) }\end{array}$} & \multicolumn{3}{|c|}{$\begin{array}{c}\text { Phosphorus uptake } \\
\text { (kg/ha) }\end{array}$} & \multicolumn{3}{|c|}{$\begin{array}{c}\text { Potassium uptake } \\
\text { (kg/ha) }\end{array}$} & \multicolumn{3}{|c|}{$\begin{array}{c}\text { Sulphur uptake } \\
\text { (kg/ha) }\end{array}$} & \multicolumn{2}{|c|}{ Yield (kg/ha) } \\
\hline & Grain & Stover & Total & Grain & Stover & Total & Grain & Stover & Total & Grain & Stover & Total & Grain & Stover \\
\hline \multicolumn{15}{|c|}{ Sulphur (kg/ha) } \\
\hline $\mathbf{0}$ & 10.73 & 12.18 & 22.91 & 4.04 & 2.95 & 6.98 & 3.55 & 10.31 & 13.86 & 3.20 & 1.08 & 4.28 & 981.31 & 2838.42 \\
\hline 15 & 12.06 & 13.79 & 25.85 & 4.67 & 3.56 & 8.23 & 4.09 & 12.85 & 16.94 & 9.15 & 1.65 & 10.80 & 1054.79 & 3176.96 \\
\hline 30 & 13.97 & 14.78 & 28.75 & 5.07 & 5.31 & 10.37 & 5.39 & 14.85 & 20.24 & 10.40 & 2.70 & 13.10 & 1146.84 & 3441.53 \\
\hline 45 & 14.87 & 16.05 & 30.92 & 5.25 & 7.29 & 12.53 & 6.00 & 16.38 & 22.37 & 12.83 & 2.87 & 15.70 & 1217.71 & 3583.33 \\
\hline $\operatorname{S~Em~}( \pm)$ & 0.29 & 0.30 & 0.39 & 0.05 & 0.06 & 0.07 & 0.10 & 0.47 & 0.47 & 0.18 & 0.15 & 0.23 & 8.29 & 18.48 \\
\hline $\mathrm{CD}(\mathrm{P}=\mathbf{0 . 0 5})$ & 0.87 & 0.90 & 1.19 & 0.15 & 0.17 & 0.21 & 0.32 & 1.43 & 1.43 & 0.54 & 0.45 & 0.70 & 25.13 & 56.06 \\
\hline \multicolumn{15}{|l|}{ Boron (\%) } \\
\hline $\mathbf{0}$ & 12.06 & 13.79 & 25.85 & 4.61 & 4.27 & 8.88 & 4.38 & 13.09 & 17.47 & 8.12 & 1.84 & 9.95 & 1070.55 & 3196.16 \\
\hline 0.15 & 13.75 & 14.61 & 28.37 & 4.91 & 5.27 & 10.18 & 5.14 & 14.11 & 19.24 & 9.67 & 2.31 & 11.99 & 1129.78 & 3323.97 \\
\hline $\operatorname{S~Em~}( \pm)$ & 0.20 & 0.21 & 0.28 & 0.03 & 0.04 & 0.05 & 0.07 & 0.33 & 0.33 & 0.13 & 0.10 & 0.16 & 5.86 & 13.07 \\
\hline $\mathrm{CD}(\mathrm{P}=\mathbf{0 . 0 5})$ & 0.62 & 0.64 & 0.84 & 0.10 & 0.12 & 0.15 & 0.22 & 1.01 & 1.01 & 0.38 & 0.31 & 0.49 & 17.77 & 39.64 \\
\hline
\end{tabular}


The boron treatment with $0.15 \%$ foliar spray of boron registered higher $(3323.97 \mathrm{~kg} / \mathrm{ha})$ stover yield and it was $3.84 \%$ more yield than the treatment without foliar spray of boron. The results are in conformity with Jadav et al., (2010) who found that higher stover yield (1043 kg/ha) was obtained with application of sulphur upto $40 \mathrm{~kg} / \mathrm{ha}$ which was at par with 20 and $50 \mathrm{~kg} / \mathrm{ha}$.

With the increase in the supply of sulphur and boron, the process of tissue differentiation from somatic to reproductive and meristematic activity and floral primordial might have increased resulting in more flowers and hence more grain setting. Sulphur application plays a vital role in the synthesis of chlorophyll which might have increased the photosynthetic rate. The increase ingrain yield is largely a function of improvement in yield attributes. The improved nutritional management as a result of the increased supply of sulphur and boron might have favorably influenced the carbohydrate metabolism and this favourable effect led to the increased transformation of photosynthates towards yield and yield attributing characters.

\section{References}

Saren, B.K., Tudu, S and Nandi, P. 2004. Effect of irrigation and sulphur application on growth and productivity of summer sesame. Madras Agriculture Journal. 91 (1-3):56-60.
Dugger, W.M. 1983. Boron in plant metabolism. Encyclopedia of Plant Nutrition. 15: 626-50.

Dwivedi, S.K, Singh, R.S. and Dwivedi, K.N. 2002. Effect of sulphur and zinc nutrition on yield and quality of maize in Typic Ustochrept soil of Kanpur. Journal of Indian Society of Soil Science. 50(1): 70-74.

Jadav, D.P., Padmani, D.R., Polara, K.B., Parmar, K.B. and Babaria, N.B. 2010. Interaction of sulphur and potassium on yield and nutrient uptake by sesame (Sesamum indicum L.). An Asian Journal of Soil Science.5(1): 144-147.

Jeena, M., Suman, J. and Indira, M. 2013. Synergistic influence of sulphur and boron on enhancing the productivity of sesame (Sesamum indicum L.) grown in an entisol of Kerala. Journal of Indian Society of Soil Science. 61(2): 122- 127.

Maragatham, S., Swamy, M.G. and Geetha, S.A. 2006. Influence of sulphur fertilization on grain yield, oil yield and sulphur uptake in sesame. Advances in Plant Sciences. 9(1): 109- 112.

Nagavani, A.V., Sumathi, V., Chandrika, V. and Muneendrababu, A. 2001. Effect of nitrogen and sulphur on yield and oil content of sesame (Sesamum indicum L.).Journal of Oilgrains Research.18 (1): 73- 74.

Panse, V.G. and Sukhatme, P.V. 1967. StatisticalMethods of Agricultural Workers. Indian Council of Agricultural Research, New Delhi.

\section{How to cite this article:}

Basant Kumar, Narayan Chandra Sarkar and Ayesha Fatima. 2020. Influence of Different Levels of Sulphur and Boron Nutrition on Nutrient Uptake and Yield of Summer Sesame in West Bengal. Int.J.Curr.Microbiol.App.Sci. 9(02): 1757-1762. doi: https://doi.org/10.20546/ijcmas.2020.902.200 